\title{
The COMPREHENSIVE PLANNING PROCESS
}

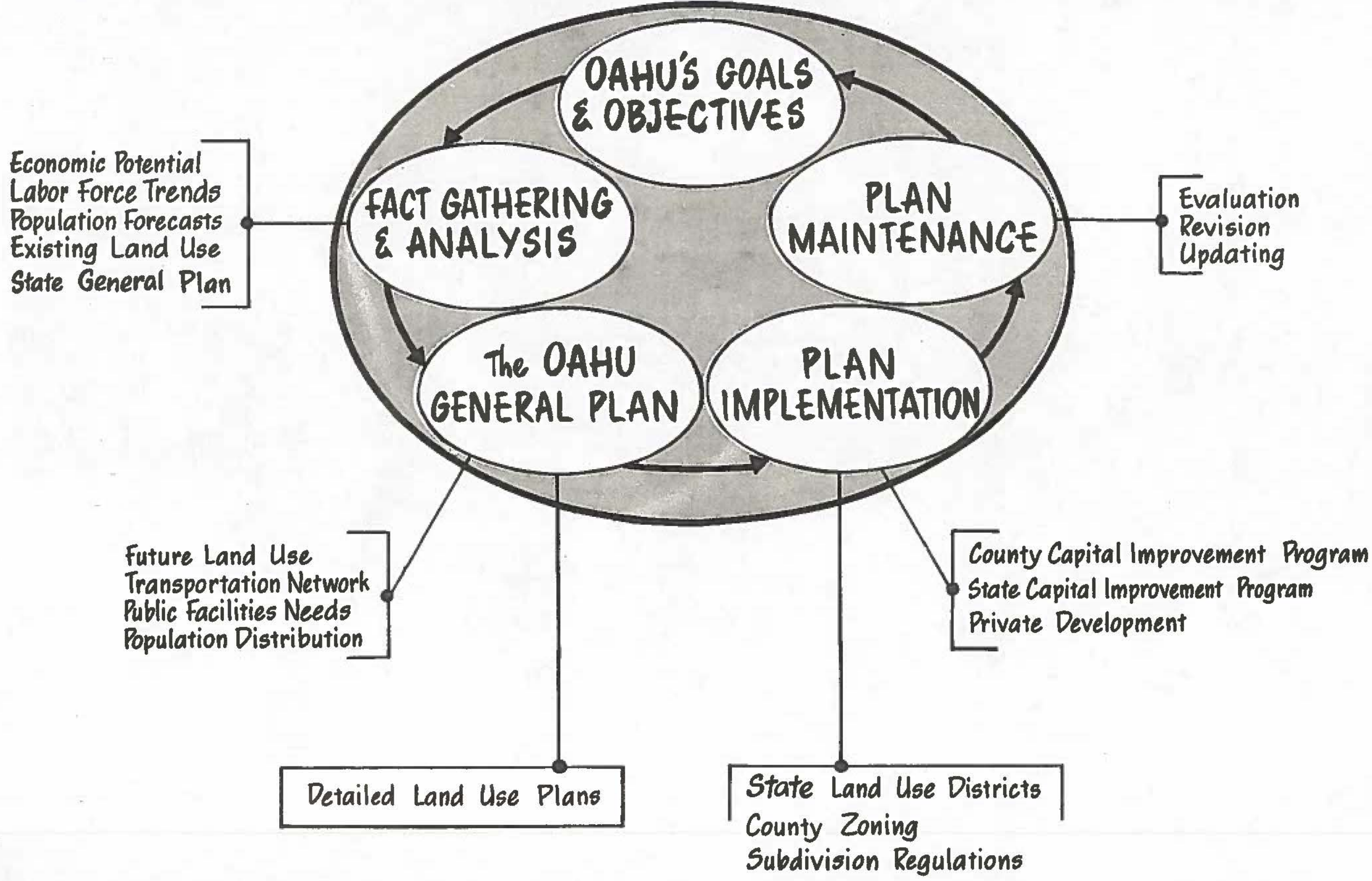

